\title{
Modal Operators and Personal Pronouns in Roosevelt's Inaugural Addresses
}

\author{
Xiaoli Dou \\ School of Foreign Languages, Chongqing Normal University, China
}

\begin{abstract}
This paper tries to apply the interpersonal function of Halliday's systemic functional grammar to analyze the interpersonal meanings of modal operators and personal pronouns in Roosevelt's four inaugural addresses, that is, the dynamic and close relationship between the speaker and the hearers. By means of statistic method and stylistic analysis, this paper takes Roosevelt's four inaugural speeches as objects of study, and mainly explores the interpersonal meanings of modal operators or linguistic forms so as to bring home Roosevelt's linguistic techniques and stylistic effects. Roosevelt shows great interest in modal operators and personal pronouns to appeal to his audience's emotional responses, to strengthen his in-group intimacy, and to convince his audience of his political purposes.
\end{abstract}

Index Terms-modal operators, personal pronouns, interpersonal function, Roosevelt's four inaugural speeches, emotional appeals

\section{INTRODUCTION}

Presidential inaugural address is a special sub-genre of public speech and a heated topic for those scholars of text analysis, but there is scant literature dealing with this topic from functional stylistics. Recently, the author has got some 1665 results by retrieving the keyword "public speech" in CNKI (Chinese National Knowledge Infrastructure), but few of them are discussed from functional linguistics. Inaugural address is delivered by the president-elect on the inauguration day, in which the speaker tries to not only present himself as the highest authority of the country but also mitigate his power to some extent in order to establish an affable or rapport relationship with the audience. On one hand, mood and modality are the linguistic realizations of the interpersonal relations between the speaker and hearers; on the other hand, the interpersonal meanings can also be realized through the system of personal pronouns. Our research data include 4 Franklin D. Roosevelt's inaugural addresses: his 1933 inaugural address in Great Depression(Text 1), 1937 inaugural address just after Great Depression(Text 2), 1941 inaugural address calling for domestic safety(Text 3) and 1945 inaugural address for peace(Text 4). By means of statistic method and stylistic analysis, this paper takes Roosevelt's four inaugural speeches as objects of study, and mainly explores the interpersonal meanings of modal operators or linguistic forms so as to bring home Roosevelt's linguistic techniques and stylistic effects.

\section{MODALITY SYSTEM}

According to functional linguistics, broadly speaking, our language perform three key metafunctions, i.e. ideational function, interpersonal function and textual function. For ideational function, we mean that by means of language, may talk about the external world around us, including discussing the things, events, qualities around us, or describe our internal world such as our thoughts, feelings, beliefs, etc. The ideational function is best represented by transitivity system or material process, i.e. whether the verb is transitive or intransitive, material process or non-material one, and physical actions are typical examples of material process, such as running, throwing, cooking, sitting down, etc.

For interpersonal function, it means that we also use language to interact with other people, to establish and maintain relations with them, to express our attitudes, views, feelings and emotions; For textual function, it means that we use some typical words or phrases to organize our messages in a cohesive, logical way.

Interpersonal function is to establish and maintain appropriate social relationships by exchanging information among people in various ways. Thompson argued that we also use language to "interact with other people: to establish and maintain appropriate social links with them." (2000, p. 44) It also expresses the speakers' attitudes, judgments, demands, expectation and their inference of the matters. It is mainly realized by the system of mood system and modality system. In addition, there are some other linguistic sources which also carry some rich interpersonal functions, such as various sentence types(declarative clauses, interrogative clauses, tag questions, exclamatory clauses, imperative clauses), personal pronouns, most adjectives, some notional words, some adverbs, etc.

Modality is considered as a chief exponent of the interpersonal function in Halliday's systemic functional linguistics. What the modality system does is to construe the region of uncertainty that lies between 'yes' and 'no'. Generally, there are two types of modality: modalization and modulation, as is shown in Table 1. 
TABLE I.

TYPES OF MODALITY

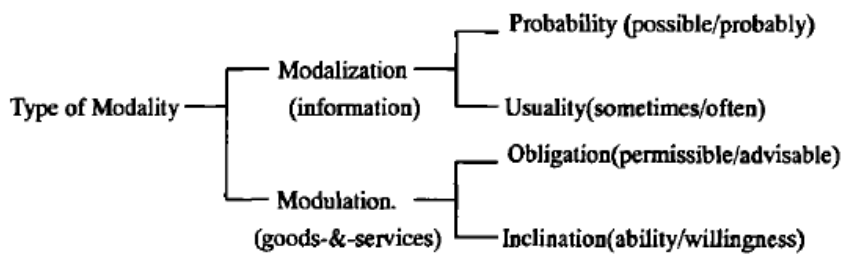

There are two types of modalization: i ) degrees of probability and ii ) degrees of usuality.

Modalization consists of probability and usuality. Probability means how likely it is to be.

Modalization refers to different degrees of likelihood between Yes and No. It consists of two sub-categories: probability and usuality. Some typical words on the probability scale are: may/might, can/could, will/would, should, must, possibly, probably, certainly, perhaps, maybe. Usuality, which means how frequency it is true, is equivalent to both yes and no, that is, the answer may be sometimes yes, sometimes no, with different degrees of oftenness attached. On the usuality scale, some typical words include may/might, can/could, will/would, should, must, usually, sometimes, often, always, never, ever, seldom, rarely.

Modulation refers to the speaker's obligation or inclination towards the statement or proposal, or the speaker's judgment of the desirability of the proposal. Some typical examples to show obligation are: may/might, can/could, should must, definitely, absolutely, at all costs, by all means; some typical examples to show inclination are: may/might, can/could, will/would, should, must, willingly, readily, gladly, certainly, easily.

Halliday argues that value is attached to the modal judgment. He distinguishes some three basic values of modality: high, median and low. (1994, p. 358) In our daily conversation, we may express a higher or lower degree of certainty about the validity of a proposition (it will/may rain), or a higher or lower degree of pressure on the other person to carry out a command (you must/should leave). Please observe the following table:

TABLE II

THREE Modal VALUES (HALLIDAY, 1994, P. 358)

\begin{tabular}{|l|l|l|l|c|}
\hline & Probability & Usuality & Obligation & Inclination \\
\hline High & certain & always & required & determined \\
\hline Median & probable & usually & supposed & keen \\
\hline Low & possible & sometimes & allowed & willing \\
\hline
\end{tabular}

Both types of modalization can be expressed in the same three ways: (1) by a finite modal operator in the verb group, e.g. that will be Mary, she'll be happy again; (2) by a modal adjuncts, e.g. That's probably Mary, she is usually very happy; (3) by both together, e.g. that will probably be Mary, she will usually sit there all day.

\section{ModAl Operators AND PERSONAl Pronouns In RoOSEVElt's AdDRESSES}

\section{A. Modal Operators}

As is discussed above, modality in clause can be realized through several ways. But it can be seen that modality is mainly realized by finite modal operators in our texts. Finite modal operators are called modal auxiliaries in their traditional term, such as will, would, can, could, may, might, shall, should, have to, ought to and so on. For their interpersonal function, they may show some possible hearer---speaker relations, ie, the interaction between the speaker and the hearers. Finite modal operators may show different degrees of meanings to unmodified utterances. In addition, these modal operators may suggest some different degrees of the speaker's feelings, emotions and attitudes towards his audience. As the newly- elected president, it is quite natural for Roosevelt to establish his a close relationship by using some typical modal operators.

Generally, modal operators can be classified into three kinds of values: high, median and low. Table 3 shows that median value accounts for the largest proportion taking up $46.43 \%$, low value covers $37.5 \%$, and high value only $16.07 \%$. 
TABLE III.

DISTRIBUTION OF FINITE MODAL OPERATORS IN FOUR ADDRESSES

\begin{tabular}{|c|c|c|c|c|c|c|c|c|c|c|}
\hline \multirow{2}{*}{ Text No. } & \multicolumn{3}{|c|}{ Low } & \multicolumn{4}{|c|}{ Median } & \multicolumn{3}{|c|}{ High } \\
\hline & may & can & could & will & would & shall & should & must & need & Have to \\
\hline 1 & 8 & 12 & 0 & 10 & 3 & 7 & 0 & 8 & 1 & 1 \\
\hline 2 & 0 & 8 & 1 & 8 & 2 & 5 & 0 & 2 & 0 & 0 \\
\hline 3 & 1 & 4 & 1 & 1 & 1 & 1 & 1 & 4 & 0 & 0 \\
\hline 4 & 1 & 4 & 2 & 6 & 0 & 7 & 0 & 2 & 0 & 0 \\
\hline Total Frequency & 10 & 28 & 4 & 25 & 6 & 20 & 1 & 16 & 1 & 1 \\
\hline Percentage & $8.93 \%$ & $25 \%$ & $3.57 \%$ & $22.32 \%$ & $5.36 \%$ & $17.86 \%$ & $0.89 \%$ & $14.29 \%$ & $0.89 \%$ & $0.89 \%$ \\
\hline
\end{tabular}

From Table 3, we can see that in our texts, three kinds of modal values - high, median and low, are distributed differently with low modal value taking up the highest percentage, high value the lowest percentage. For low value, can is the most frequently used modal operator and covers some $25 \%$ of the total modal operators, may $8.93 \%$, could $3.57 \%$; For median value, will takes up the highest percentage, $22.32 \%$, shall $17.86 \%$, and must $14.29 \%$; For median value, must take up the highest $14.29 \%$, need and have to the lowest. So can, will, shall and must are among the most frequently employed modals in Roosevelt's speeches. On the other hand, modality refers to "varying degrees" the addresser commits a proposition to truth. Clearly, Roosevelt inclines to avoid being too aggressive and radical when he intends to intrude his own ideas and attitudes towards his audience.

1. High-value Modal Operators

It can be seen from Table 3 that must appears most frequently for 18 times and takes up 14.29\%. According to Halliday (1994/2000), must carries the highest degree of obligation in the sphere of modulation, which implies that the speaker is in a strong position to carry out his future policies. The newly- elected president tries to avoid giving some orders or making some requirements, which may hurt the audience. However, high value modal operators are quite necessary in some specific situations and contribute to the realization of interpersonal meanings in the addresses, e.g.:

(1) If I know aught of the spirit and purpose of our Nation, we will not listen to Comfort, Opportunism, and Timidity. We will carry on. (Text 2)

(2) A nation, like a person, has a body--a body that must be fed and clothed and housed, invigorated and rested, in a manner that measures up to the standards of our time. (Text 3 )

(3) A nation, like a person, has a body---a body that $m u s t$ be fed and clothed and housed, invigorated and rested, in a manner that measures up to the objectives of our time. (Text 3)

Here, Roosevelt uses must to influence the audience's opinions and call them on into action. For one thing, he keeps his stand as the president of America by giving irresistible suggestion. For anther thing, he avoids too direct ways by the $1^{\text {st }}$-person form $I$ or we as subject. By doing that, he establishes a harmonious relation with his audience.

In conclusion, high value finite modal operators can be employed to call for action, but because of their heavy imposition on the audience, the addressers incline not to use them frequently.

2. Median-value Modal Operators

There are 25 instances of will in the texts, reaching $22.32 \%$ of the entire modal operators. We know, will is used to provide information about what will happen in the future and the statement made about coming occurrences that are based on the addressers' predictions, belief and intentions rather than on their knowledge of fact. Moreover, will can be used in sentences with an obvious modal use of permission. For examples:

(3) If I know aught of the will of our people, they will demand that these conditions of effective government shall be created and maintained. They will demand a nation uncorrupted by cancers of injustice and, therefore, strong among the nations in its example of the will to peace. (Text 2)

(4) This great Nation will endure as it has endured, will revive and will prosper. (Text 1)

(5) In this process evil things formerly accepted will not be so easily condoned. Hard-headedness will not so easily excuse hardheartedness. We are moving toward an era of good feeling. But we realize that there can be no era of good feeling save among men of good will. (Text 2)

In the above examples, Roosevelt employs 8 wills to show his predictions, intentions, beliefs and attitudes. He plans to tell the audience these wills are not his own but the entire Americans'. In a conclusion, these statements enhance his status as a president and enforce his will on the audience, too.

In a word, the median value modal operator will is often used to show a prediction and commitment. With the help of will, the addressers are confident in bringing the audience the benefits of the offer. As long as the audience is talked into accepting the actualization of the promise, the addressers achieve their interpersonal function.

3. Low-value Modal Operators

According to the study of the texts, low finite modal operators takes $37.5 \%$ of the total, among which can is used most frequently. The low finite modal operators are helpful for Roosevelt to intrude his attitude in more polite manner. Besides, can accounts for $25 \%$ and appears 28 times in all. Through the study of the texts, can is often applied to denote 
three kinds of the meanings: possibility, ability and permission. They can be illustrated by examples in our texts.

(6) Small wonder that confidence languishes, for it thrives only on honesty, on honor, on the sacredness of the obligation, on faithful protection, on unselfish performance; without them it can not live. (Text 1)

(7) If I read the temper of our people correctly, we can not merely take but we must give as well. (Text 1)

(8) There are many ways in which it can be helped, but it can never be helped by merely talking about it. We must act, we must act quickly. (Text 2)

In example (6), can is often employed to express possibility. Possibility carries a very low modal value among the three basic dynamic meanings of can. In this sense, can expresses a kind of potentiality, which helps to elicit and aspire hopes from the audience and put Roosevelt in a position of the authority to predict the future and thus obtain the audience's acceptation and identification. Example (7) uses can not to refuse to a grant permission. Roosevelt indicates that to build a strong nation, people need to devote themselves instead of taking from the country. Moreover, in example (8) Roosevelt employs can to express his determination to fulfill his presidential duty. Thus the use of can will bring more confidence and support for him from the audience.

In general, Roosevelt makes full use of low value finite modal operators to avoid being too aggressive and leave the audience room to decide by themselves. Therefore, a more comfortable atmosphere for communication has been set up.

\section{B. Personal Pronoun System}

As a grammatical category, person indicates the number and nature of the participants in a situation, and distinctions of person are usually marked in the verb and in the associated personal pronouns. Halliday holds that studying the interpersonal meaning of the pronouns in specific situation is possible and meaningful. A basic distinction is made into speech roles $(I, w e, y o u)$ and other roles (she, he, it, they). In effect, in a language address, the interpersonal metafunction is the interaction between $I$ and you. They are the speaker and the hearer. Nevertheless, the nature of the address determines that they are a social-political role in a broader sense. When the speaker is given the role to deliver a speech, he is also endowed to suggest, to inform and to give orders. So personal pronouns are the reflection of the speaker's attitude and his social relationship to the hearers. Clearly, personal pronouns themselves are rarely "neutral" in their references. Please see Table 4.

TABLE IV.

DISTRIBUTION OF PERSONAL PRONOUNS IN FOUR ADDRESSES

\begin{tabular}{|c|c|c|c|}
\hline $\begin{array}{c}\text { Personal } \\
\text { Pronouns }\end{array}$ & 1st Person & 2nd Person & 3rd Person \\
\hline 1 & 40 & 1 & 18 \\
\hline 2 & 80 & 3 & 7 \\
\hline 3 & 41 & 0 & 2 \\
\hline 4 & 18 & 1 & 4 \\
\hline Total Frequency & 179 & 5 & $14.02 \%$ \\
\hline Percentage & $83.64 \%$ & $2.34 \%$ & \\
\hline
\end{tabular}

Table 4 illustrates that the first person is used most frequently, covering $83.64 \%$ of the total, the third person is $14.02 \%$, taking the second place and the second person is the least one, only $2.34 \%$ of the total. Besides, after a careful examination, we can see that the first person we is used for 142 times, I 37 times, they/he 30 times and you 5 times. The uses of personal pronouns produce different scales of psychological effects between the speaker and the audience. We can find the reasons why the speakers tend to use more we than you in public speeches, which can shorten psychological distance between the speaker and the hearer. Therefore, the following section will put emphases on these personal pronouns.

1. First Person Pronoun

In political addresses, the plural form of the first person pronoun we is used widely by the speaker to achieve different interactive effects. Besides, Halliday claims that the use of the pronoun we can be either inclusive or exclusive. When it refers to both the speaker and the audience, we is inclusive. When it excludes the audience but only includes the speaker and his party or associates, we is exclusive. Identity marker we is a linguistic strategy to show the speaker's positive politeness by including both real and potential hearers in an activity of interaction.

(9) We face the arduous days that lie before $u s$ in the warm courage of the national unity. (Text 1)

(10) To us there has come a time, in the midst of swift happenings, to pause for a moment and take stock--to recall what our place in history has been, and to rediscover what we are and what we may be. (Text 3)

At the end of the first inaugural speech, Roosevelt describes the common adversity and purpose of the whole Americans. So In example (9), we refers to Roosevelt himself and all the Americans for the purpose of uniting people of America. At last, by applying we he places himself in the same stand as the audience and at the same time, he tries to mitigate his power to ask for their support. While in example (10), we is used to remind the American people of their glorious history and their urgent obligations as well. Here, we is inclusive and he wants to stress his status, which makes 
the speech more convincing.

2. Second Person Pronoun

In common sense, you in discourse refers directly to the addressee. It both realizes its deictic function and indicates a certain interpersonal function between the speaker and the hearer. The use of you shows the lower status of the listener in comparison with the higher social status of the speaker. So often you is used less frequently in our texts, only 5 times. But the pronoun you is also an essential part of successful communication.

(11) I am convinced that you will again give that support to leadership in these critical days. (Text 1)

(12) If you and I, if we in this later day, lose that sacred fire--if we let it be smothered with doubt and fear--then we shall reject the destiny which Washington strove so valiantly and so triumphantly to establish. (Text 3 )

In examples (11) and (12), you refers to not only the audience on the spot but those who are in other parts of the country. Roosevelt selects you to show his awareness of the potential audience. He hopes all the audience to realize his caring about them and expecting their support.

It can be seen that personal pronoun you achieves the effects to attract the hearer' attention fully, strengthen the interaction between the speaker and the hearers and maintain his status as the president of the USA. Generally, the $2^{\text {nd }}$ person pronoun you is seldom used in Roosevelt's addresses.

3. Third Person Pronoun

Here, the third personal pronoun indicates the third party which is separated from the first and second forms. Adoption of third personal pronoun means that the speaker wants to project authority more than to keep equal relationship with the audience. By doing so, his remarks appear more formal and authoritative. Under such circumstance, the speaker puts more attention to the objectivity of his speech than the communication purpose with his audience.

(12) In such a spirit on my part and on yours we face our common difficulties. They concern, thank God, only material things. (Text 1)

(13) If I know aught of the will of our people, they will demand that these conditions of effective government shall be created and maintained. They will demand a nation uncorrupted by cancers of injustice and, therefore, strong among the nations in its example of the will to peace. (Text 2)

Roosevelt plans to provoke the audience to be aware of the serious problems. The existence of the third party can inspire the audience to stand with him. So, third person they drives the audience to turn to Roosevelt. As a result, the employment of they may strengthen affiliation between Roosevelt and the audience. A proper use of third personal pronoun can make the proposition objective and reliable, though too many third persons may leave the audience an impersonal impression.

\section{CONCLUSION}

This paper tries to apply the interpersonal function of Halliday's systemic functional grammar to analyze the interpersonal meanings of modal operators and personal pronouns in Roosevelt's four inaugural addresses, that is, the dynamic and close relationship between the speaker and the hearers. By means of statistic method and stylistic analysis, this paper takes Roosevelt's four inaugural speeches as objects of study, and mainly explores the interpersonal meanings of modal operators or linguistic forms so as to bring home Roosevelt's linguistic techniques and stylistic effects. Modalization consists of probability and usuality, which may best show the speaker's attitudes, emotions and stances towards his audiences. Our four tables and rich examples show that Roosevelt shows great interest in modal operators and personal pronouns to appeal to his audience's emotional responses, to strengthen his in-group intimacy, and to convince his audience of his political purposes. We may see that three kinds of modal values - high, median and low, are distributed differently with low modal value taking up the highest percentage, high value the lowest percentage. From those modal values, we find that Roosevelt inclines to avoid being too aggressive and radical when he intends to intrude his own ideas and attitudes towards his audience. In addition, the first person plural we is used widely by the speaker to achieve different interactive effects, which is a linguistic strategy to show the speaker's positive politeness by including both real and potential hearers in an activity of interaction. As a useful technique for the newly- elected president, the personal pronouns mainly consist in its reflection of the relationship between the participants in the interaction. Through our careful study, we may conclude that the personal pronouns carry some strong interpersonal meanings and they are conducive both to building a strong in-group relationship between the speaker and his participants and to convincing them of his political ideas and his governing policies.

\section{REFERENCES}

[1] Brown, G. \& G. Yule. (1983). Discourse Analysis. Cambridge: Cambridge University Press.

[2] Campbell, K, \& Jamieson, K. (1990). Deeds Done in Words: Presidential Rhetoric and the Genres of Governance. Chicago: University of Chicago Press.

[3] Eggins, S. (2004). An Introduction to Systemic Functional Linguistics. London: The Continuum Publishing Co.

[4] Halliday, M. A. K. (1994). Language as Social Semiotic: the Social Interpersonal Interpretation of Language and Meaning. London: Edward Arnold.

[5] Halliday, M. A. K. (2000). An Introduction to Functional Grammar. 2nd Edition. Beijing: Foreign Language Teaching and 
Research Press.

[6] Hu Zhuanglin. (2000). Functionalism. Beijing: Foreign Language Publication Press.

[7] Keizer, E. (2015). A Functional Discourse Grammar for English. Oxford: Oxford University Press.

[8] Lemke, J. L. (1992). Interpersonal Meaning in Discourse. London and New York: Pinter.

[9] Li Zhanzi. (2000). Interpersonal Meaning in Discourse. Peking: Peking University.

[10] Martin, J. R. \& D. Rose. (2007). Working With Discourse: Meaning Beyond the Clause. London: Continuum International Publishing Group Ltd.

[11] Paltridge, B. (2017). Discourse Analysis. London: Bloomsbury Academic.

[12] Thompson, G. (2000). Introducing Functional Grammar. Beijing: Foreign Language Teaching and Research Press.

[13] Wales, K. (1996). Personal Pronouns in Present-day English. Cambridge: Cambridge University Press.

[14] Xu Zhengzhong. (1995). The Style of Lincoln's Public Speeches. Foreign Language Teaching, No 1, 87-91.

Xiaoli Dou is currently a lecturer of English at School of Foreign Languages and Literatures, Chongqing Normal University, China, and her research interests cover foreign language teaching and English stylistics. 